\title{
THE EVALUATION OF CUSTOMER SATISFACTION SURVEY FOLLOW-UP IN LPPOM MUI
}

\author{
Hendra Utama*1, Sukardi**), and Taufik Djatna**) \\ *) School of Business, IPB University \\ Jl. Raya Pajajaran, Bogor 16151, Indonesia \\ ${ }^{* *}$ Department of Agroindustrial Technology, Faculty of Agriculture Technology, IPB University \\ Jl. Dramaga, IPB Darmaga Campus, Bogor 16680, Indonesia
}

\begin{abstract}
Customer satisfaction survey is a standard method used by service providers in order to obtain feedback from the customer as well as close the gap between customer expectation and perception of service quality. Feedback from customers can make them possible to define the level of quality of service by themselves. If a service provider can satisfy its customers, it means that it will retain its customers. LPPOM MUI, as an authorized halal certifying body in Indonesia, has conducted a customer satisfaction survey three times from 2015 up to 2017. After conducting the survey, LPPOM also performed a follow-up based on the result of the survey. The purposes of this research are (1) to get to know about the follow-up of customer satisfaction evaluation of LPPOM MUI, (2) to analyze the impact of the follow-up implementation progress versus reevaluation by LPPOM MUI's customer group on the follow-up, (3) to provide recommendation(s) if the customers perceive the follow-up implementation still does not fulfill their service quality expectation. The methods used were a qualitative analysis based on the follow-up of LPPOM MUI's customer satisfaction survey versus re-evaluation on LPPOM MUI's seven customer groups on the follow-up. The result shows that all quality service attributes need improvement to meet customer expectations. They are namely 1) the ease of contacting the Call Center 14056 or LPPOM MUI, 2a) The availability of notification if any change or dysfunction of CEROL SS-23000 and 2b) replying time to customer email (3a) Dealing time to halal certification process (3b) dealing time to post-audit stage (3c) Dealing time to LPPOM MUI approval of new material of the company.
\end{abstract}

Keywords: service quality, customer satisfaction survey, follow-up, LPPOM MUI, re-evaluation

\begin{abstract}
Abstrak: Survei kepuasan pelanggan adalah metode umum yang digunakan penyedia jasa untuk mendapatkan umpan balik dari pelanggan sekaligus mendekati harapan pelanggan terhadap kualitas pelayanan. Umpan balik tersebut adalah salah satu cara pelanggan untuk mendefinisikan sendiri kualitas pelayanan yang diinginkannya dari penyedia jasa. Jika sebuah penyedia jasa dapat memuaskan pelanggannya, berarti penyedia jasa tersebut dapat mempertahankan pelanggannya. LPPOM MUI sebagai penyelenggara jasa sertifikasi halal di Indonesia telah melakukan survei kepuasan pelanggan 3 kali di dalam kurun waktu 2015-2017. Hasil survei kepuasan pelanggan tersebut dijadikan dasar untuk tindak lanjut perbaikan pelayanan oleh LPPOM MUI. Tujuan penelitian ini adalah (1) mengetahui tindak lanjut evaluasi kepuasan pelanggan, (2) menganalisis dampak tindak lanjut terhadap kebutuhan perbaikan atribut pelayanan yang diharapkan pelanggan dan (3) memberikan rekomendasi perbaikan jika hasil tindak lanjut atas perbaikan atribut pelayanan belum memenuhi harapan pelanggan. Metode yang digunakan adalah analisis deskriptif kualitatif atas tindak lanjut survei kepuasan pelanggan dibandingkan dengan respon kelompok pelanggan setelah dilakukan perbaikan perbaikan pelayanan. Tindak lanjut perbaikan dilakukan untuk 5 atribut dengan kesenjangan terbesar antara harapan dan pengalaman pelayanan pelanggan. Tindak lanjut hasil evaluasi ulang kelompok pelanggan atas perbaikan yang dilakukan LPPOM MUI ternyata masih belum memenuhi harapan semua kelompok pelanggan. Semua atribut yang sudah diberikan tindak lanjut perbaikan ternyata masih belum memenuhi harapan pelanggan adalah 1) kemudahan dalam menghubungi telepon dan call center 14056,2a) pemberitahuan jika terjadi perubahan atau gangguan Cerol, dan 2b) kecepatan dalam merespon email (3a) kecepatan proses sertifikasi halal (3b) kecepatan respon pasca audit dan (3c) kecepatan proses izin penggunaan bahan baru
\end{abstract}

Kata kunci: kualitas pelayanan, survei kepuasan pelanggan, tindak lanjut, LPPOM MU,I reevaluasi

\footnotetext{
${ }^{1}$ Corresponding author:

Email: hendra.utama1970@gmail.com
} 


\section{INTRODUCTION}

As an authorized halal certifying body in Indonesia, LPPOM MUI committed to always focus on its customer satisfaction. The commitment stated in a quality policy, a document which elaborated and established from its organization's vision, mission, and values. The quality policy of LPPOM MUI is to being a nation-wide and world-class trustable halal certifying body that always prioritizes the customer satisfaction through enhancing continuous improvement, maintaining the value of trust, of professional, of transparent, of accountable, of quick and proper service which aligned with Islamic law. Regarding the quality service to customers, it can observed from LPPOM MUIS's quality policy that LPPOM MUI commits to fulfill customer satisfaction through the delivery of service quickly and adequately. Customer satisfaction is an essential factor in growing the business, including the service sector. Sumarwan (2003) states that customer satisfaction is the impact of a comparison between customer satisfaction before and after the transaction happened. The satisfaction level of buyers/customers depends on service performance (quality) in order to satisfy them. Liniere (2013) adds factors that influence customer satisfaction are an expectation, pricing, quality, value, e-commerce, brand, reputation, and nature of goods or services. Customers' experience will influence their expectations in the future, and in turn, it will influence their satisfaction. Recognition on customer satisfaction is relevant in order to identify the reason for decreasing customer satisfaction. Customers expectation represents their standard by making a perception of real life (experience of a transaction) (Grunwald and Hempelmann, 2010). In other words, customers expectation constructed in order to accept a certain quality of service level.

LPPOM MUI is managing customers of 3030 halalcertified companies. The companies categorized into 7 (seven) customer groups. The customer groups categories are divided based on haram critical level risk, a number of material used in the company of customer groups, and the number of production facilities used in the company among customer group members. Customer group A is halal certified companies that have lowest risk of a haram critical level, the lowest number of materials used, and the lowest number of production facilities used. Meanwhile, customer group F is halal certified companies that have the highest risk of a haram critical level, the highest number of materials used, and the highest number of production facilities used. Customer group $\mathrm{G}$ is categorized as service provider company (for instance: logistics, transporter, and retailer) (LPPOM MUI, 2018).

LPPOM MUI has been providing halal certification service since 1994. At the time, service had been provided manually up to 2012. Since2012,LPPOMMUI started to use an online registration application portal website to serve its customers what-so-called CEROL SS-23000. LPPOM MUI has used the increase of information technology and communication availability in facilitating the halal certification registration process for customers which does not depend on time, space and place. These all aligned with de Ruyter et al. (2001) that state that e-quality service can be defined as customer service, which is interactive, online-based content, customer-driven, integrated with processing and technology that supports the organization and has objective to strengthen the relationship between a service provider and customer. E-service includes interactively process flow started from upstream into the downstream process. At the upstream process, e-service includes e-procurement and supply chain functionality. Meanwhile, at the downstream process, e-service includes customer relationship management, relation marketing, one to one marketing, and customer care.

At every process stage, there is a process owner who is responsible that ensures any tasks which are done by his/her staff that fulfills the quality target and timelines of the process stage as mentioned in LPPOM MUI's quality manual. In other words, for a business process developed by LPPOM MUI, for every customer that proceeded for every process stage-managed by the different process owner. As depicted in Figure 1, Table 1 describes 18 critical control points (CCP) of halal certification service that shall controlled, which is aligned with quality target and timelines, as explained in LPPOM MUI's quality manual. Actors that involved in the process flow chart are Finance Division, Auditing Division, Halal Assurance System Division, Fatwa Commission Administration sub-division, Halal Certification Administration sub-division, and LPPOM MU's Customers. 


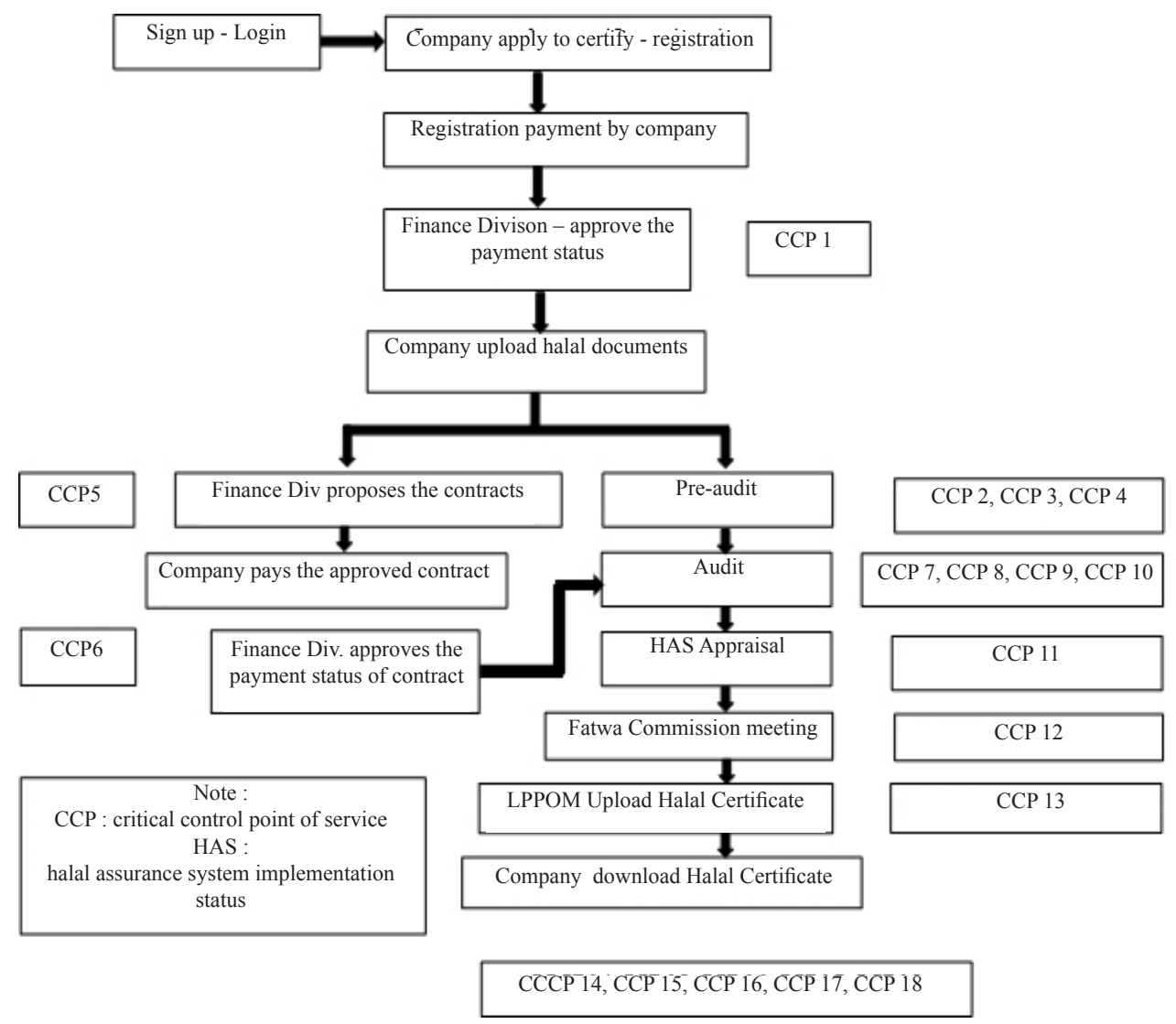

Figure 1. Business process of MUI halal certification and critical control point of service

Table 1. LPPOM MUI halal certification process and its critical control points of service

\begin{tabular}{|c|c|c|c|}
\hline СCP & $\begin{array}{l}\text { Responsible } \\
\text { Division }\end{array}$ & Process in detail & Quality target and its timeline \\
\hline CCP 1 & $\begin{array}{l}\text { Finance } \\
\text { Division }\end{array}$ & $\begin{array}{l}\text { Finance division will verify and approve the } \\
\text { registration payment status of a company } \\
\text { through CEROL SS- } 23000 \text { application }\end{array}$ & Maximum 3 days \\
\hline ССР2 & $\begin{array}{l}\text { Halal } \\
\text { Assurance } \\
\text { System (HAS) } \\
\text { Division }\end{array}$ & $\begin{array}{l}\text { HAS Division will review the company } \\
\text { registration documents }\end{array}$ & Maximum 4 days \\
\hline $\mathrm{CCP} 3$ & $\begin{array}{l}\text { Auditing } \\
\text { Division }\end{array}$ & $\begin{array}{l}\text { Auditing Division will do pre-audit process } \\
\text { (materials, matrices of material versus product, } \\
\text { and auditing note) with the parallel process with } \\
\text { HAS Division }\end{array}$ & Maximum 7 days \\
\hline СCP4 & HAS Division & $\begin{array}{l}\text { HAS Division will do pre-audit process with } \\
\text { parallel process with Auditing Division }\end{array}$ & Maximum 11 days \\
\hline CCP5 & $\begin{array}{l}\text { Finance } \\
\text { Division }\end{array}$ & $\begin{array}{l}\text { Finance Division will draft and propose the } \\
\text { contract of halal certification to the company }\end{array}$ & $\begin{array}{l}\text { Maximum } 6 \text { days after pre-audit process is } \\
\text { complete }\end{array}$ \\
\hline ССР6 & $\begin{array}{l}\text { Finance } \\
\text { Division }\end{array}$ & $\begin{array}{l}\text { Finance Division will do the approval process } \\
\text { of the contract payment status of the company } \\
\text { through CEROL SS-23000 application }\end{array}$ & $\begin{array}{l}\text { Maximum } 4 \text { days after company signing and } \\
\text { uploading the contract into CEROL SS- } \\
23000\end{array}$ \\
\hline CCP7 & $\begin{array}{l}\text { Auditing } \\
\text { Division }\end{array}$ & $\begin{array}{l}\text { Auditing Division will make an audit schedule, } \\
\text { appoint the auditors team, and review audit } \\
\text { report of auditors }\end{array}$ & $\begin{array}{l}\text { Auditor team appointment will made } \\
\text { maximum one day before visiting the } \\
\text { company (local company), } 7 \text { days (overseas } \\
\text { company) }\end{array}$ \\
\hline
\end{tabular}


Table 1. LPPOM MUI halal certification process and its critical control points of service (continue)

\begin{tabular}{|c|c|c|c|}
\hline $\mathrm{CCP}$ & $\begin{array}{l}\text { Responsible } \\
\text { Division }\end{array}$ & Process in detail & Quality target and its timeline \\
\hline CCP8 & Auditor & $\begin{array}{l}\text { An auditor will conduct an audit, make a report } \\
\text { of the audit, and present the report at auditors } \\
\text { meeting }\end{array}$ & $\begin{array}{l}\text { Auditor will update the report into CEROL } \\
\text { SS- } 23000 \text { maximum } 4 \text { days after auditing in } \\
\text { local companies dan } 11 \text { days after auditing } \\
\text { in overseas companies }\end{array}$ \\
\hline СCP9 & HAS Division & $\begin{array}{l}\text { HAS Division will review auditor's report } \\
\text { regarding Halal Assurance Implementation in } \\
\text { company }\end{array}$ & Maximum 3 days after auditors meeting \\
\hline CCP10 & $\begin{array}{l}\text { Auditing } \\
\text { Division }\end{array}$ & $\begin{array}{l}\text { Auditing Division will review the compliance } \\
\text { of halal material documents that reported by } \\
\text { auditors }\end{array}$ & $\begin{array}{l}\text { If meeting concluded the documents is still } \\
\text { lacking, audit memorandum would send } \\
\text { to the company by uploading into CEROL } \\
\text { SS- } 23000 \text { maximum } 14 \text { days after auditors } \\
\text { meeting (if materials number less than } 150 \text { ), } \\
21 \text { days if materials number more than } 151 \\
\text { but less than } 500 \text { and } 28 \text { days if materials } \\
\text { number more than } 500\end{array}$ \\
\hline CCP11 & HAS Division & $\begin{array}{l}\text { HAS Division will review HAS implementation } \\
\text { of the company and issue HAS implementation } \\
\text { quality document }\end{array}$ & Maximum 3 days after auditors meeting date \\
\hline CCP12 & $\begin{array}{l}\text { Fatwa } \\
\text { Commission } \\
\text { Administration } \\
\text { Sub-Division }\end{array}$ & $\begin{array}{l}\text { Fatwa Commission Administration Sub-Division } \\
\text { will prepare audit reports to present in the Fatwa } \\
\text { Commission meeting and keep the records of the } \\
\text { meeting. }\end{array}$ & $\begin{array}{l}\text { Maximum one day before the fatwa } \\
\text { commission meeting }\end{array}$ \\
\hline CCP13 & $\begin{array}{l}\text { Halal } \\
\text { Certification } \\
\text { and HAS } \\
\text { Administration } \\
\text { Sub-Division }\end{array}$ & $\begin{array}{l}\text { Halal Certification and HAS Administration } \\
\text { Sub-Division will prepare the halal certificate } \\
\text { and HAS documents, proceed the signing of the } \\
\text { documents and upload all documents in pdf file } \\
\text { format into CEROL SS- } 23000\end{array}$ & Maximum 30 days \\
\hline CCP14 & $\begin{array}{l}\text { Customer } \\
\text { Service Sub- } \\
\text { Division }\end{array}$ & $\begin{array}{l}\text { Customer Service Sub-Division manages call } \\
\text { center } 14056 \text { and customer complaints }\end{array}$ & $\begin{array}{l}\text { If any miss called to contact the call center, } \\
\text { so then the CS staff will call them back in } \\
\text { the same day (at the end of the day) }\end{array}$ \\
\hline CCP15 & All Divisions & $\begin{array}{l}\text { All divisions will reply email that sent by an } \\
\text { external party }\end{array}$ & $\begin{array}{l}\text { Maximum one day after receiving the email } \\
\text { except auditing, HAS, and Finance Division } \\
\text { that will reply the maximum email 3days }\end{array}$ \\
\hline CCP16 & $\begin{array}{l}\mathrm{R} \text { and } \mathrm{D} \\
\text { Division }\end{array}$ & $\begin{array}{l}\mathrm{R} \text { and } \mathrm{D} \text { Division manages all requisition of the } \\
\text { usage of new materials from the company }\end{array}$ & Maximum 5 days \\
\hline CCP17 & $\begin{array}{l}\text { Management } \\
\text { Information } \\
\text { System (MIS) } \\
\text { Division }\end{array}$ & $\begin{array}{l}\text { MIS Division maintains the functionality of } \\
\text { CEROL SS- } 23000 \text { all days }\end{array}$ & $\begin{array}{l}\text { MIS Division will fix if any dysfunction } \\
\text { occurred with CEROL SS-23000 }\end{array}$ \\
\hline CCP18 & $\begin{array}{l}\text { Auditing and } \\
\text { HAS Division }\end{array}$ & $\begin{array}{l}\text { Both of Divisions will review any documents } \\
\text { that arebeing followed up by the company }\end{array}$ & Maximum 7 days \\
\hline
\end{tabular}

In recognizing customer expectation on certain service quality level, LPPOM MUI conducts customer satisfaction evaluation and open the access for the customers to raise complain about quality service and appeals on halal certification decision. Customer satisfaction evaluation and complaining of customers is a form of feedback from customers on the quality service level provided by service providers.
LPPOM MUI conducted a customer satisfaction survey three times within 2015-2017. The customer satisfaction survey employed five dimensions of the ServQual model approach (Parasuraman et al. 1988). From the five dimensions, then they were developed into 20 quality attributes. The five dimensions are reliability, assurance, tangibles, empathy, and responsiveness. Quality attributes that developed from the dimensions are five attributes for reliability, three attributes for assurance, two attributes for tangible, six for empathy, 
and four for responsiveness. Because LPPOM MUI has been operating e-service since 2012, so the attributes designed aligned with seven dimensions of e-service quality that were developed by Parasuraman et al. (2005). They are efficiency, system availability, fulfillment, privation, responsiveness, compensation, and contact dimensions.

The first four dimensions related to e-service quality, and the last three dimensions related to e-service recovery. Efficiency defined as a dimension which related to the level of ease, accessible, and speed of website. Jayawardhena and Foley (2000) and Yang and Fang (2004) proved in their research that accessibility is a very critical factor in customer satisfaction. The system availability dimension defined as a website that technically works. Wolfinbarger dan Gilly (2003) dan Parasuraman et al. (2005) define that fulfillment dimension as an important factor in e-service quality and customer satisfaction. The privacy dimension is defined as a degree or level of website security. Many pieces of research have examined the importance of privacy dimension on customer perception (Law and Leung (2002); Santos (2003), Yang and Fang (2004) dan Zeithaml et al. (2002) and customer satisfaction (Lin, 2007; Szymanski and Hise, 2000).

Responsiveness dimension defined as a website able to be effective as a problem solver (Parasuraman et al. 2005). The responsiveness dimension related to the intension of the company to assist the customer and to provide quick service to the customer who needs helps. Few pieces of research have proven that the responsiveness dimension influences customer perception on e-service quality and e-customer satisfaction (Lee dan Lin 2005; Yang dan Fang 2004; Yang dan Jun 2002).

The compensation dimension is defined as the degree of website ability to provide compensation to the consumer for every problem that arises. Meanwhile, the contact dimension is defined as any assistance available via phone or online media as infrastructure for a company to give clarification or confirmation for every problem faced by the customer.

Beside dimensions that were developed by Parasuraman et al. (2005), in many studies in the context of e-service quality also used other dimensions such as esthetic website design (Yoo and Donthu 2001); functionality, communication, trust, and innovation (Loiacono et al. 2002); information quality and interaction quality between organization and customers in service (Francis and White, 2002); enjoyment and process (Bauer et al. 2006) and personalization (Liu et al. 2010)

For every stage of the business process of halal certification at LPPOM MUI, was evaluated by customers to compare between customer expectation and customer perception on LPPOM MUI service quality. The result of the customer satisfaction survey measured with the Customer Satisfaction Index (Irawan, 2003) and gap score calculation between customer expectation and customer perception on LPPOM MUI service quality. From the gap score, then, were selected top 5 attributes that had the highest score as a priority to provide some improvement in quality service to customers.

The top five attributes that had selected based on survey data analysis were brought by QA and Standard team to the Board of Directors (BOD) of the LPPOM MUI meeting. This meeting is to decide the follow-up of customer satisfaction survey officially results in a way to improve customer perception on LPPOM MUI service quality had been so far. Besides customer satisfaction surveys, complaint(s) that delivered by customer(s) were also as inputs for BOD for deciding the follow-up of a customer satisfaction survey.

The follow-up (in the context of customer satisfaction survey), according to Hesselbein et al. (1996), is a sort of progress report which functions as a tool to identify the progress on the making and also as a medium of getting feedback from customer for the follow-up improvement. In order to analyze whether the implementation of the follow-up of customer satisfaction survey result that already met the need for improvement demanded by the customer, then it is necessary for the re-evaluation by customers themselves. Therefore, this research intended to figure out the follow-up of the customer satisfaction survey that deployed by LPPOM MUI. The follow-up, then, will be as a basis to analyze the impact on needs of LPPOM MUI service quality improvement demanded by customers, based on the re-evaluation from customer groups to ensure whether the deployment of the follow-up already fulfilled customer perception on the expected service quality level. If the customer groups consider the deployment of the follow-up of customer satisfaction survey not yet fulfilled the customer expectation and LPPOM MUI quality target that established by the management of 
LPPOM MUI, then, in this research will be suggested some points of recommendation to close the gap of customer expectation and quality standard of LPPOM MUI service.

However, pieces of research have done by several researchers related to customer satisfaction, which stressed to the survey or evaluation of customer satisfaction. However, this research emphasized to evaluate the follow-up of customer satisfaction surveys that had been done by LPPOM MUI in order to check whether the follow-ups already fulfilled the needs of customer expectation on service quality improvement.

Research Objective to figure out the follow-up of customer satisfaction survey result which were done by LPPOM MUI; To analyze the impact of the followup of customer satisfaction survey based on customer perception on the improvement needs of LPPOM MUI quality service; To propose any recommendation to LPPOM MUI if, according to the perception of customers still perceive some weaknesses found.

\section{METHODS}

The research held at the LPPOM MUI office during September - October 2018. The research performed with descriptive methods. Data used are primary as well as secondary. In order to answer research objective no 1 , the primary data collected through an open questionnaire, in depth-interview, and activity observations. The interview conductedwith LPPOM MUI QA and Standard team which consisted of Head of Division, two sub-head of division) and Vice Director III. In order to answer the research objective no 2, the primary data was collected through open questionnaire from every representative of customer group which was selected purposively based on the most complex of halal critical materials in the company, the highest number of materials used in the company, and the highest number of production facilities used in the company among the customer group members. The represented company gave the feedback about the impact that was experienced by it, on the follow-up of customer satisfaction survey which was done by LPPOM MUI as "a progress report" for quality service level improvement that conducted by LPPOM MUI for top 5 attributes with the highest gap (between expectation and perception of the customer on LPPOM MUI quality service level) score. In order to answer the research objective no 3 , the impact of the follow-up analysis result according to the perception of customer group, then, were calculated the percentage of customer group that perceived the improvement of quality service level not yet fulfilled their expectation and compared with LPPOM MUI management quality target (by 20\%). If the customer group did not satisfy with every attribute of more than $20 \%$, then this research will provide some recommendations. Recommendations for improvement per attribute will complimented with managerial implication based on the existing condition of LPPOM MUI. Meanwhile, secondary data collected from relevant research and information, which are sourcing from LPPOM internal reports, documents, and records as well as scientific journals, books, proceedings, and working papers.

The research process would outline four stages namely first is LPPOM MUI business process identification and its relationship with customer satisfaction evaluation, second is customer satisfaction evaluation result and its follow-up. Third is the re-evaluation of customer group onto the follow-up of customer satisfaction survey which was done by LPPOM MUI, and the last is of a recommendation of improvement if the impact of the follow-up execution did not fulfill the customer expectation and the quality target of management of LPPOM MUI.

\section{RESULTS}

\section{The follow-up of Customer Satisfaction Evaluation Result}

A follow-up, according to Hesselbein et al. (1996), is “a progress report" functions as a tool to identify progress and as a media to request a feedback from a customer. The follow-up is essential for the sake of improvement in the future. In the context of LPPOM MUI customer satisfaction evaluation, so the follow-up that conducted by LPPOM MUI is to make a list of action plans that had a timeline in order to close the gap of improvement needs that expected by the customer of LPPOM MUI. After getting the result of customer satisfaction evaluation, so the LPPOM MUI, later on, made the follow-up based on the result. From the calculation of the top 5 attributes that had the highest gap score, the priority of improvement of quality service level would come to the top 5 attributes themselves. Generally, the improvement based on the root-cause-analysis that 
had an impact on the gap happens between customer expectation and perception on the service quality that served by the LPPOM MUI. Table 2 is containing the customer satisfaction evaluation result and its followup per attribute.
The follow-up that conducted per attribute above expected to fulfill the improvement need on each attribute of the top 5 attributes which had the highest gap score based on the customer satisfaction evaluation result in the year 2017 .

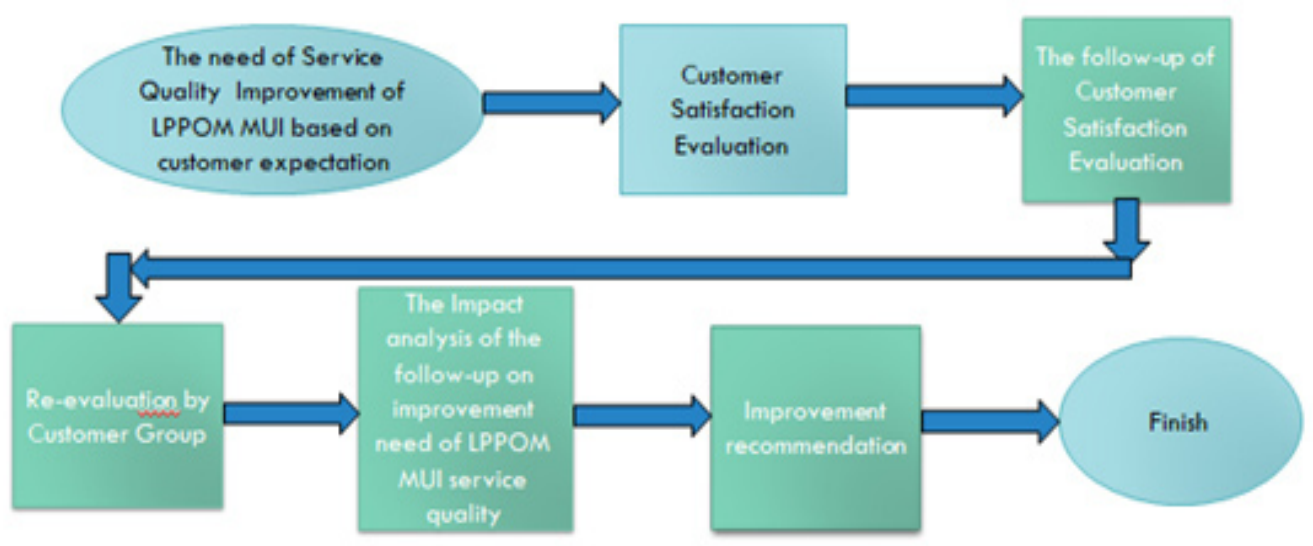

Figure 2. Research framework

Table 2. The result of customer satisfaction evaluation and its follow-up

\begin{abstract}
The top 5 of attributes with the highest score gaps

The availability of notification if any change or dysfunction of CEROL SS-23000 (Gap Score:1.167)(Dimensions: responsiveness)

The ease of contacting the Call Center 14056 or LPPOM MUI phone (Gap Score: -1.100)

(Dimension: responsiveness)
\end{abstract}

Replying time of LPPOM MUI to customer email (Gap score: -0.867) (Dimension: responsiveness)

Dealing time to halal certification process (Gap score: -0,833) (Dimension: reliability)

Dealing time to halal certification process (Gap score: -0.767) (Dimension: assurance) Dealing time to LPPOM MUI approval of new material of the company (Gap Score: -0,767) (Dimension: empathy)
The Follow-up

To make maintenance system hence every dysfunction of CEROL SS-23000 can be anticipated; If any change and dysfunction of CEROL SS-23000 happen, so the customers will be notified via email; To recruit any additional staff of Management Information System

To switch the menu of call center 14056 with Indonesia language; To add phone lines to become three lines; For one of them, during $(03.00-05.00 \mathrm{pm})$ will be used to recall the missed call customer by call; To check monthly call center performance; To communicate externally to customer-related the availability of call center through email and flyers; To inform the alternative channel to customers of WhatsApp number as a medium of clarification anything and questioning issues related with a halal certification process

To establish procedure related to the replying of the customer email maximum three days for auditing, halal assurance system, and finance division and one day for other divisions; To conduct service excellence training; To propose the program of customer relationship management to management of LPPOM MUI; Only email address of services@halalmui.org that will published to customers.

To analyze the work burden of all activities related to the business process of halal certification and to review the timeline of every process step at every procedure; To monitor the achievement of a quality target at every processing step of CEROL SS23000; To estimate the optimum timeline of the halal certification process in detail from the pre-audit stage, audit stage, and post-audit stage up to halal certificate issuance; To update the questionnaire of customer satisfaction evaluation by including of quality target issue per every stage of the halal certification process

Same as the above attribute

Same as the above attribute 
The Impact Analysis of the Follow-up of Customer Satisfaction Evaluation versus the Re-evaluation from Customer Group

In order to measure the impact of the follow-up of improvement done by LPPOM MUI so then it was done a re-evaluation from each representative company of customer group A up to customer group G. Each representative company gave the re-evaluation for the top 5 attributes of customer satisfaction evaluation result. Table 3 is containing the re-evaluation of each representative company of customer group A up to customer G.
From the feedback that given by the customer group on the follow-up of customer satisfaction evaluation result that performed by LPPOM MUI, in fact, not all the follow-up fully meet the expectation of all customer groups even though among customer groups did not every group gave the same feedback. Table 4 is containing the percentage of customer groups that assess the following attributes that did not entirely fulfill the expectation of the customer group.

Table 3. Customer group re-evaluation result on the follow-up of improvement per attributes

Top five attributes of the Re-evaluation of customer group on the follow-up

highest gap score

The availability of notification if any change or dysfunction of CEROL SS23000

The ease of contacting the Call Center 14056 or LPPOM MUI phone

Replying time to customer email
Group A (Kelompok A): Regarding with functionality of CEROL SS-23000, it has been excellent, but there is no notification regarding any change or dysfunction of CEROL SS-23000

Group B (Kelompok B): there is no notification regarding with any change or dysfunction of CEROL SS-23000

Group $\mathrm{C}$ (Kelompok $\mathrm{C}$ ): there is no notification regarding with any change or dysfunction of CEROL SS-23000

Group D(Kelompok D): it has already met the expectation

Group E (Kelompok E): it has already met the expectation

Group F (Kelompok F): there is no notification regarding with any change or dysfunction of CEROL SS-23000

Group G (Kelompok G): it has already met the expectation

Group A (Kelompok A): not yet fulfilled the expectation

Group B (Kelompok B): not yet fulfilled the expectation

Group C (Kelompok C): not yet fully fulfilled the expectation, singularly if any phone of call center 14056 can not be contacted, but it still available alternative phone lines

Group D (Kelompok D): it has already met the expectation

Group E (Kelompok E): not yet fulfilled the expectation, it suggested to add more alternative phone lines

Group F (Kelompok F): not yet fulfilled the expectation, it is not easy to phone call center, because it is too many layers of processing step before starting to speak with the customer service staff

Group G (Kelompok G): not yet fulfilled the expectation

Group A (Kelompok A): it has already met the expectation

Group B (Kelompok B): not yet fulfilled the expectation, it needed more than two days

Group C (Kelompok C): it has already met the expectation

Group D (Kelompok D): it has already met the expectation

Group E (Kelompok E): not yet fulfilled the expectation mainly for the complicated question, that needs to coordinate across the division in answering it

Group F (Kelompok F): nearly fulfilled the expectation, but if the email sent completed with copy carbon (cc) of other division letting to know the email, please reply to the email with copy carbon too.

Group G (Kelompok G): not yet fulfilled the expectation, it was still replied in the next day or two days later 
Table 3. Customer group re-evaluation result on the follow-up of improvement per attributes (continue)

\begin{tabular}{|c|c|}
\hline $\begin{array}{l}\text { Top five attributes of the } \\
\text { highest gap score }\end{array}$ & Re-evaluation of customer group on the follow-up \\
\hline \multirow{7}{*}{$\begin{array}{l}\text { Dealing time to halal } \\
\text { certification process }\end{array}$} & Group A (Kelompok A): it has already fulfilled the expectation \\
\hline & $\begin{array}{l}\text { Group B (Kelompok B): it has not yet fulfilled the expectation especially to review the } \\
\text { compliance of documents }\end{array}$ \\
\hline & Group C (Kelompok C): it has already fulfilled the expectation \\
\hline & Group D (Kelompok D): it has already fulfilled the expectation \\
\hline & Group E (Kelompok E): it has already fulfilled the expectation \\
\hline & Group F (Kelompok F): it has not yet fulfilled the expectation especially \\
\hline & $\begin{array}{l}\text { Group } G(\text { Kelompok } G) \text { : it has already fulfilled the expectation, except the renewal } \\
\text { process of halal certification }\end{array}$ \\
\hline \multirow{7}{*}{$\begin{array}{l}\text { Dealing time to post-audit } \\
\text { process }\end{array}$} & Group A (Kelompok A): it has already fulfilled the expectation \\
\hline & $\begin{array}{l}\text { Group B (Kelompok B): it has not yet already fulfilled the expectation primarily related } \\
\text { to dealing time of follow-up document review }\end{array}$ \\
\hline & Group C (Kelompok C): it has already fulfilled the expectation \\
\hline & Group D (Kelompok D): it has already fulfilled the expectation \\
\hline & Group E (Kelompok E): it has already fulfilled the expectation \\
\hline & Group F (Kelompok F): it has already fulfilled the expectation \\
\hline & Group $\mathrm{G}$ (Kelompok $\mathrm{G})$ : it has already fulfilled the expectation \\
\hline \multirow{7}{*}{$\begin{array}{l}\text { Dealing time to LPPOM MUI } \\
\text { approval of new material of } \\
\text { the company }\end{array}$} & Group A (Kelompok A): it has already fulfilled the expectation \\
\hline & Group B (Kelompok B): it has not yet fulfilled the expectation, it was more than four days \\
\hline & $\begin{array}{l}\text { Group C (Kelompok C): it has already fulfilled the expectation, except document failure } \\
\text { to upload there is no notification that failure happened }\end{array}$ \\
\hline & Group D (Kelompok D): it has already fulfilled the expectation \\
\hline & Group E (Kelompok E): it has nearly fulfilled the expectation \\
\hline & Kelompok F: it has already fulfilled the expectation \\
\hline & Kelompok G: not applicable (this sort of company does not have materials used \\
\hline
\end{tabular}

Tabel 4. The customer group re-evaluation result that perceived improvement conducted for the top five attributes with the highest gap score not yet fulfilled the customer expectation and LPPOM MUI quality target

\begin{tabular}{lcc}
\hline \multicolumn{1}{c}{ The Attributes } & $\begin{array}{c}\text { Failed to meet } \\
\text { Customer } \\
\text { Expectation (\%) }\end{array}$ & $\begin{array}{c}\text { Quality } \\
\text { target (\%) }\end{array}$ \\
\hline Replying time to customer email & $71.43 \%$ & $20 \%$ \\
The availability of notification if any change or dysfunction of CEROL SS-23000 & $57.14 \%$ & $20 \%$ \\
Replying time to customer email & $57.14 \%$ & $20 \%$ \\
Dealing time to halal certification process & $28.57 \%$ & $20 \%$ \\
Dealing time to LPPOM MUI approval of new material of the company & $28.57 \%$ & $20 \%$ \\
\hline
\end{tabular}

Based on the re-evaluation (customer perceptions) on the impact analysis of improvement done by LPPOM MUI as the follow-up of the customer satisfaction survey, so all attributes were still considered not fulfilling their expectation. Indeed, they were following attributes that arranged based on the highest percentage to the lowest of no fulfilling the expectation based on customer perception: The ease of contacting the phone and call center 14056; the availability of notification if any change or dysfunction of CEROL SS-23000; Replying time of LPPOM to customer email; Dealing time to halal certification process; Dealing time to postaudit process; Dealing time to LPPOM MUI approval of new material of the company. 


\section{Recommendation of Improvement for Attributes which do not Fulfill the Service Quality Target of LPPOM MUI}

For all attributes that do not fulfill the quality target of service level that stated by LPPOM MUI management so the recommendations of improvement as depicted in Table 5.

\section{Managerial Implications}

Based on the recommendation of improvements, so here are the managerial implications for LPPOM MUI management: 1) Needing to add some other phone lines for Call Center 14056 and/or add operational time, which in line with the workload analysis of call center staff in answering the phone; 2) Monitoring and controlling the procedure deployment by staff in replying the email of customers which is in line with quality target per division; 3) Revising the procedure and having to be in line with the quality target of every customer group for every process stage of halal certification. Service quality standard also has to be in line with customer groups. In order to ensure the quality target, every process stage monitored and controlled by the in-charge person; 4) Disseminating the quality target as part of LPPOM MUI external communication to the customer when the quality target per customer group has established in order to avoid misperception following standard service timeline; 5) Upgrading the CEROL SS-23000 application. It aims to make an easily usage by customers, so the additional features shall added to save time either for LPPOM MUI internally or for the customer to operate it. This includes a dashboard of quality target control (either timeline or person in charge), as well as notification of quality target from LPPOM MUI for the customer for every processing stage and every customer group; 6) Redesigning the customer satisfaction evaluation questionnaire by including issues related to customer complaint and questions which related to quality target.

Table 5. Recommendations for improvements for attributes based on customer group re-evaluation

\begin{tabular}{lcl}
\hline Atribut & Re-evaluation result $(\%)$ & Recommendations \\
\hline $\begin{array}{l}\text { The ease of contacting the phone line } \\
\text { or Call Center } 14056\end{array}$ & $71,43 \%$ & To add phone line /operational time \\
$\begin{array}{l}\text { the availability of notification if any } \\
\text { change or dysfunction of CEROL SS- }\end{array}$ & $57,14 \%$ & $\begin{array}{l}\text { To monitor the implementation of the procedure to } \\
\text { ensure the quality target has fulfilled }\end{array}$
\end{tabular}

replying time to customer email

$57,14 \%$

dealing time of halal certification process

$28,57 \%$

dealing time to post-audit process

$28,57 \%$

dealing time of LPPOM MUI approval to new material usage process
The maintenance of CEROL SS-23000 is always kept and increased its quality and the adding of features of CEROL SS-23000

The establishment of service quality standard per customer group hence it is necessary to change their procedures, to disseminate and monitor the implementation of quality target achievement, to re-design the questionnaires of quality satisfaction evaluation by including LPPOM MUI quality target aspect

The establishment of service quality standard per customer group hence it is necessary to change their procedures, to disseminate and monitor the implementation of quality target achievement, to re-design the questionnaires of quality satisfaction evaluation by including LPPOM MUI quality target aspect

$28,57 \% \quad$ The establishment of service quality standard per customer group hence it is necessary to change their procedures, to disseminate and monitor the implementation of quality target achievement, to re-design the questionnaires of quality satisfaction evaluation by including LPPOM MUI quality target aspect 
Implementing recommendation of improvement suggested by the author is challenging. For several recommendations, LPPOM MUI considered to be able to implement them soon, but for others, they will need time and investment. For managerial implication no 1, it will be needed an analysis for call center working staff burden. Hence it can be decided whether adding phone lines or operational time. For managerial implication no 4 and 5, it will need investment for upgrading CEROL SS-23000. Meanwhile, for managerial implication no 3, it will need follow-up research with a cluster analysis approach per service dimension and attribute. For managerial implication no 6, it can be implemented in the next year of customer satisfaction evaluation.

The benefit of this research are to provide some valuable inputs to Vice Director III of LPPOM MUI, who manages supporting facilities for the MUI halal certification process. Hence they can be used for making any decisions that related to LPPOM MUI customer satisfaction evaluation and its follow-up. Besides Vice Director III, this research result is also valuable for LPPOM MUI QA and Standard team because the result can be used for improving customer satisfaction evaluation program for the next year and its followup and effectively in making a plan of improvement of quality service level that will be accepted by LPPOM MUI customers. The result of this research will also be as valuable information for LPPOM MUI Management Information System Division because it can be a fundamentalbasis for improvement and development of CEROL SS-23000 application for the next-version.

\section{CONCLUSIONS AND RECOMMENDATIONS}

\section{Conclusions}

The follow-up of the LPPOM MUI customer satisfaction survey in the year 2017 conducted in order to improve the service level of quality for the top 5 attributes with the highest gap score between customer expectation and customer perception on service quality level that served by LPPOM MUI. The top 5 attributes were (1) The ease of contacting the phone line or Call Center 14056; (2) the availability of notification if any change or dysfunction of CEROL SS-23000; (3) replying time to customer email; (4) dealing time of halal certification process; (5a) dealing time to post-audit process; (5b) dealing time of LPPOM MUI approval to new material usage process.
The follow-up conducted by LPPOM MUI on customer satisfaction survey did not entirely fulfill the needs of service quality improvement based on customer perception. The attributes that perceived by customer group did not entirely fulfill the needs of improvement are as follows: (1) the ease of contacting the Call Center 14056 or LPPOM MUI phone (which perceived by $71.43 \%$ of customer groups failed to meet their expectation); (2a) replying time to customer email; (2b) the availability of notification if any change or dysfunction of CEROL SS-23000 (for 2a and 2b, which perceived by $57.14 \%$ of customer groups); (3a) dealing time of halal certification process; ( $3 b)$ dealing time to post-audit process; (3c) dealing time of LPPOM MUI approval to new material usage process (for $3 \mathrm{a}, 3 \mathrm{~b}, 3 \mathrm{c}$, which perceived by $28,57 \%$ of customer groups).

In order to close the gap of a quality target that expected by LPPOM MUI, which is no more than $20 \%$. The managerial implication ssuggested are (1) Needing to add some other phone lines for Call Center 14056 and/or add operational time which in line with the working staff burden analysis of call center staffs in answering the phone; (2) Monitoring and controlling the procedure deployment by staff in replying the email of customers which is in line with quality target per division; (3) Revising the procedure and having to be in line with the quality target of every customer group for every process stage of halal certification; (4) Disseminating the quality target as part of LPPOM MUI external communication to the customer when quality target per customer group has been already established in order to avoid misperception following standard service timeline; (5) Upgrading the CEROL SS-23000 application, in order to make it easily used by customers; and (6) Redesigning the customer satisfaction evaluation questionnaire by including issues related with customer complaint and questions which are related with the quality target.

\section{Recommendations}

The first limitation is data and information that gathered as research basis only from March up to October 2018, therefore not all action plans for service level improvement. Hence, some action plans maynot have conducted yet, so the customers have not experience the improvement as expected. The second limitation, service level standard established by LPPOM MUI only based on the number of material used for products that are to be halal certified. The company that has materials 
with a range of 0-150 items, LPPOM MUI staff, will serve the customers based on the standards of service maximum 14 days. In fact, for customer groups A, B, and $\mathrm{C}$, they have only materials, not more than 20 . If LPPOM MUI staff serves the customer group A, B, and $\mathrm{C}$ with spending time not more 14 days, according to the quality target of LPPOM MUI is still acceptable.

Meanwhile, the customer group A, B, and C, expect not such a long time, it may be only expected not more than two days. This different perception between LPPOM MUI staff and the company makes this result in research as if LPPOM MUI never improved every attribute that is prioritized to improve or at least not fulfilled the expectation of customers. That is why, in order to fulfill the customer expectation, in this research, it suggested to make quality service standards for every customer group is different. The method used to realize this suggestion is to apply a cluster analysis approach per dimension per attribute per customer group. Hence it can result as output is the service quality standards for every customer group.

\section{REFERENCES}

Barnes SJ, Vidgen RT. 2002. Assessing e-commerce quality with WebQual: an evaluation of the usability, information quality, and interaction quality of internet bookstores. Journal of Electronic Commerce Research 3: 114-127.

Bauer HH, Falk T, Hammerschmidt M. 2006. eTransQual:Atransactionprocess-basedapproach for capturing service quality in online shopping. Journal of Business Research 59: 866-875. https://doi.org/10.1016/j.jbusres.2006.01.021.

de Ruyter K, Wetzels M, Kleijnen M. 2001. Customer Adoption of E-Service: An Experimental Study. International Journal of Service Industry Management 12 (2):184-207. https://doi. org/10.1108/09564230110387542.

Francis JE, White L. 2002. Exploratory and confirmatory factor analysis of the Perceived Internet Retailing Quality (PIRQ) model. Proceedings of ANZMAC 1 January 2002. Deakin University Australia.

Grunwald G, Hempelmann $\quad$ B. 2010. Impacts of reputation for quality on perceptions of company responsibility and product-related dangers in times of product-recall and public complaints crises: results from an empirical investigation. Corporate Reputation Review 13(4): 264-283. https://doi.org/10.1057/crr.2010.23.

Hesselbein F, Goldsmith M, Beckhard, R. 1996. The Drucker Foundation: The Leader of the Future. Jossey-Bass, San Francisco.

Irawan H. 2003, Indonesian Customer Satisfaction. Jakarta: PT. Elex Media Komputindo.

Jayawardhena C, Foley P. 2000. Changes in the banking sector - the case of Internet banking in the UK. Electronic Networking Applications and Policy 10(1): 19-31. https://doi. org/10.1108/10662240010312048.

Law R, Leung R. 2000. A study of airline's online reservation service on the Internet. Journal of Travel Research 39(2): 202-211. https://doi. org/10.1177/004728750003900210.

Lee GG, Lin HF. 2005. Customer perceptions of e-service quality in online shopping. International Journal of Retail \& Distribution Management 33(2/3): 161-176. https://doi. org/10.1108/09590550510581485.

Lin HF. 2007. The impact of website quality dimensions on customer satisfaction in the B2C e-commerce context. Total Quality Management and Business Excellence 18(4): 363-378. https:// doi.org/10.1080/14783360701231302.

Liniere M. 2013. Factors that contribute to the decline of customer satisfaction in banking [disertasi]. Minnesota: Walden University.

Liu CT, Guo YM, Lee CH. 2011. The effects of relationship quality and switching barriers on customer loyalty. International Journal of Information 31: 71-79. https://doi.org/10.1016/j. ijinfomgt.2010.05.008.

Loiacono ET, Watson RT, Goodhue DL. 2002. WebQual: A measure of website quality. American Marketing Association Conference Proceedings: 432-438.

[LPPOM MUI]. 2018. Laporan Tahunan Kinerja LPPOM MUI. Dokumen internal LPPOM MUI (tidak dipublikasikan). Bogor: LPPOM MUI Pusat

Parasuraman A, Zeitham V, Berry L. 1988. SERQUAL: a multiple item scale for measuring customer perception of service quality. Journal of Retailing 64(1): 12-40.

Parasuraman A, Zeitham V, Malhotra A. 2005. E-SQUAL: a multiple item scale for assessing electronic service quality. Journal of Service Research 7(3): 213-230. https://doi. org/10.1177/1094670504271156.

Santos J. 2003. E-service quality: a model of 
virtual service quality dimensions. Managing Service Quality 13(3): 233-246.https://doi. org/10.1108/09604520310476490.

Sumarwan U. 2003. Perilaku Konsumen. Jakarta:Ghalia Indonesia.

Szymanski DM, Hise RT. 2000. E-satisfaction: an initial examination. Journal of Retailing 76: 309-322. https://doi.org/10.1016/S00224359(00)00035-X.

Wolfinbarger M, Gilly MC. 2003. eTailQ: dimensionalizing, measuring and predicting etail quality. Journal of Retailing 79 (3): 183-198.https://doi.org/10.1016/S00224359(03)00034-4.
Yang Z, Fang X. 2004. Online service quality dimensions and their relationship with satisfaction: a content analysis of customer reviews of securities brokerage services. International Journal of Service Industry Management 15(3): 302-326.

Yang Z, Jun M. 2002. Consumer perception of e-service quality: from internet purchaser and non-purchaser perspectives. Journal of Business Strategies 19(1): 19-41. https://doi. org/10.1108/09564230410540953.

Zeitham V, Parasuraman A, Malhotra, A. 2002. An emperical examination of the service qualityvalue-loyalty chain in electronic channel. Working Paper. University of North Carolina. 